\title{
GST-A Game Changer in Indian Tax Structure
}

\author{
${ }^{1}$ (Dr Geetanjali Sharma, ${ }^{2}$ (Mrs.Miriam George, \\ ${ }^{1}$ Asst Professor, Dept of MBA, CMRIT Bangalore/VTU/India, \\ ${ }^{2}$ Asst Professor, Dept of MBA, CMRIT, Bangalore/VTU/India
}

\begin{abstract}
The research paper focuses on the importance of Goods and Services Tax(GST) embodied recently in the Indian Tax structure. The paper discusses the genesis of Indian Taxation System with reference to the Arthasastra and Revenue Act of 1924. The contents of the research paper include the evolution of GST in India. The research objectives focuses around the evolution of GST, the comparison of present and GST tax structure, How GST will function in India, the economic implication of GST which unifies India and the basic challenges faced in GST. The milestones of GST have been discussed to analyze how it impacts India's economic environment. The transition of GST to an amalgamated structure has also. The economic implications of GST in India, the challenges and roadblocks faced in India have been depicted in this research paper. The paper also illustrates how GST works in India.
\end{abstract}

Keywords: GST, Goods and services tax, Indian Tax, Indian tax structure, Indian tax scenario

\section{Genesis Of Indian Taxation: A New Outlook:}

The Constitution Amendment Bill for Goods and Services Tax has been approved by the President of India in the Rajya Sabha on August 03, 2016 and August 08, 2016 in Lok Sabha. The intention is to replace all the indirect taxes levied on goods and services and implement GST by April 2017. This brings out the significance of the history on Indian taxation system.

In India the system of taxation (direct taxation) dates back from ancient times, the references of which we read in Arthasastra. Manu the ancient sage and Law-giver stressed on the importance of taxes which public should comprehensively and compulsorily pay to the Kings according to their income levels. Similarly, the Kautilyas of Arthasastra dealt with the system of taxation wherein the state was to provide necessary services including taxes imposed on goods imported from outside the country.

In the year 1924, central Board of Revenue Act constituted the Board as statutory body with the responsibility for the administration of income tax. Since then there have been plethora of amendments .with the widening of tax net various recommendations of expert committee's like Indian taxation Enquiry committee(1924-25) ,The taxation Enquiry commission ( 1953-54) were undertaken. The objectives of tax reforms were as follows:

1. Simplification of tax laws.

2. Widening tax base.

3. Restructuring income tax department to increase effectiveness and productivity

\section{Literature Review:}

Aurobindo Panda, Atul Patel, The Impact of GST on the Indian Tax Scene, SSRN Electronic Journal, July 201, DOI: $10.2139 /$ ssrn.1868621.

The paper discusses on the impact of GST on Indian Tax Scenario, the need for change in tax structure from traditional to GST Model. The paper has vividly described the salient features and impact of GST in 2011. The other facets of GST include the limitation of the tazx structure, the need for GST, the Kelkar Shah Model etc have been included in the research paper which gives a complete understanding of GST.

NehaKanojia, A Study on Godds and services Tax in India, the International Journal of Social science and Management, ISSN: 22511571

The paper discusses on the benefits of GST and it's current implication in India. The current system of indirect taxes is not able to implicate tax evasion and distortion. It also indicates how GST is an improvement over VAT and Service Tax.

\section{Monika Sehrawat, UpasanaDhanda, GST in India: A Key Tax Reform, International Journal of Research} Granthalaya, Vol 3, No: 12(2015) 133-141

The paper focuses on the overview of GST concept, the features along with it's time line of implementation in India with the challenges faced in it's implementation. It includes an exploratory research. It includes implementation to threshold limit. 
Nishita Gupta, Goods and Services Tax: it's impact on Indian Economy, International Research Journal of Commerce Arts and Science, Vol 5, Issue 3, Year-2014, ISSN 2319-9202.

The research paper focuses on the relevance of VAT and GST , how GST contributes to the improvement of the tax structure in india toward a world class system. The paper included intricate details of VAT. It indicated a significant improvement in the the comprehensive indirect tax reforms in the country. It discusses about the differences in treatment for the service and manufacturing sector. It has also included the integration of taxation with an intend to harmonize the consumption tax system.

\section{Research Objectives:}

The particular study is an attempt undertaken to analyze the following objectives:

1. Evolution of GST.

2. Comparing Present Tax structure and GST

3. How GST would function in India

4. The Challenges in implementing GST

5. The Economic Implications of GST-System of unifies India

\section{Research Methodology:}

The research paper has gathered data based on secondary research and information gathered fromthe other research papers, the current affairs, news dailies and the current GST discussion etc have been imperative in framing this conceptual paper.

\section{An Insight into Evolution of GST In India:}

India is one of the latest growing economies to adopt GST. It also featured latest to adopt the VAT as well. The Southeast Asian economies adopted consumption taxes like the VAT, or the GST based on valueaddition way back in the 1980s and 1990s.Laos, one of the least developed countries (LDCs) from the region implemented VAT from 2009, four years after India did. Malaysia was an interesting exception which introduced a GST of 6 per cent only from April 1, 2015. InSouth Asia, Bangladesh, Sri Lanka, Pakistan and Nepal had VAT implemented from the 1990s, latest by early-2000s.

The key to an effective GST is that it has to enhance production. Most countries, while imposing VAT, was not been able to entirely eliminate regressive nature of indirect taxes. A comparison of the different rates of GST over few countries is given below in figure 3.1.Scandinavian countries have standard rate of 25 per cent, which is amongst the world's highest, followed by Uruguay and Argentina from the Latin American region with rates of 22 per cent and 21 per cent respectively.

Thepurported Indian revenue neutral rate of 17 per cent,will be considered above the averages in Asia. Southeast Asia has an average rate of around 7.7 per cent.

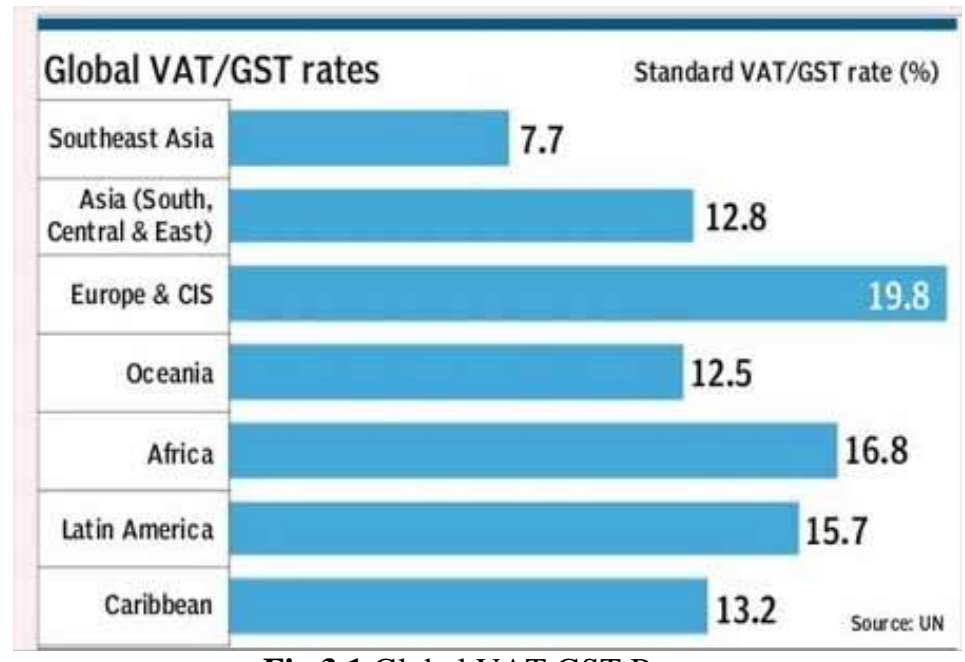

Fig 3.1 Global VAT GST Rates

Indirect taxes in India have proved to be better suited as they have much wider coverage as compared to direct taxes. Excise duty has been major source of income.The base of excise duty have tremendously increased due to the introduction of new commodities from year to year.

A beginning towards adoption of VAT in Indiawas made in 1986 when MODVAT was introduced Professor Raja J Chellaih chairman -national Institute of public Finance and policy called in Tax Reforms 
committee. The committee suggested VAT (value added Tax) for rationalising the tax structure. During the period 1992-97, the excise duty structure was modified to gradually reduce the high rates of duties on several commodities. While there were concerted efforts to rationalize the rate structure, the fact remains that system with multitude taxes both by centre and state have only diminished the capacity to generate buoyant revenues, created revenue leakages and collusion and corruption. The cascading effect of taxes led to serious distortions of commodity prices. There were unprecedented disputes in the administration, implementation and interpretation of legal text of MODVAT and CENVAT (central value added tax) Credit schemes.

\section{GST- Major Milestone:}

- The idea of GST was first introduced and in budget 2006-2007. The empowered committee of state finance ministers (EC) formulated the design of GST .If VAT was a major improvement then GST is seen as another milestone towards tax reforms.

- GST have been described by political analyst as the concept of "cooperative financial federalism" and one nation one tax one market.

- GST is claimed to be game changing tax reform as it will pave way for common national market. This would facilitate free movement of goods and services across the country.

Present Tax Structure:

\section{Comparison Of Present Tax And GST Tax:}

The existing tax structure of India has been indicated in the Fig 1.1 below. This shows the relation between direct tax, income tax, indirect tax, central excise, VAT, entry, luxury tax etc.

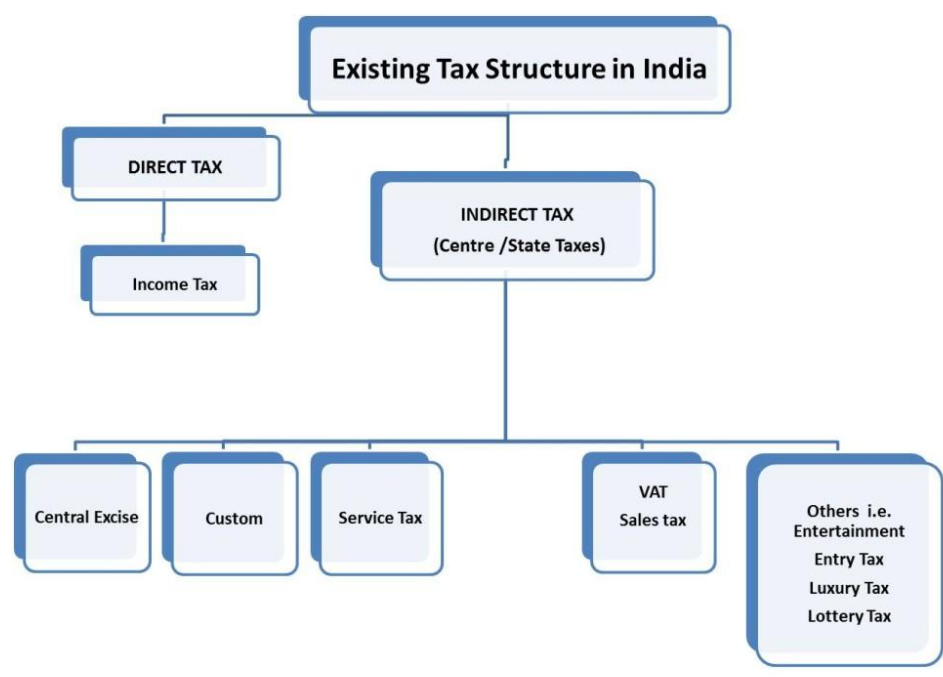

Fig 5.1 Existing Tax Structure Of India

\section{GST Tax Structure:}

The fig 6.1 shows the GST Tax structure which shows the relation between Intra state GST, Inter state GST, central GST, state GST, Integrated GST etc. 


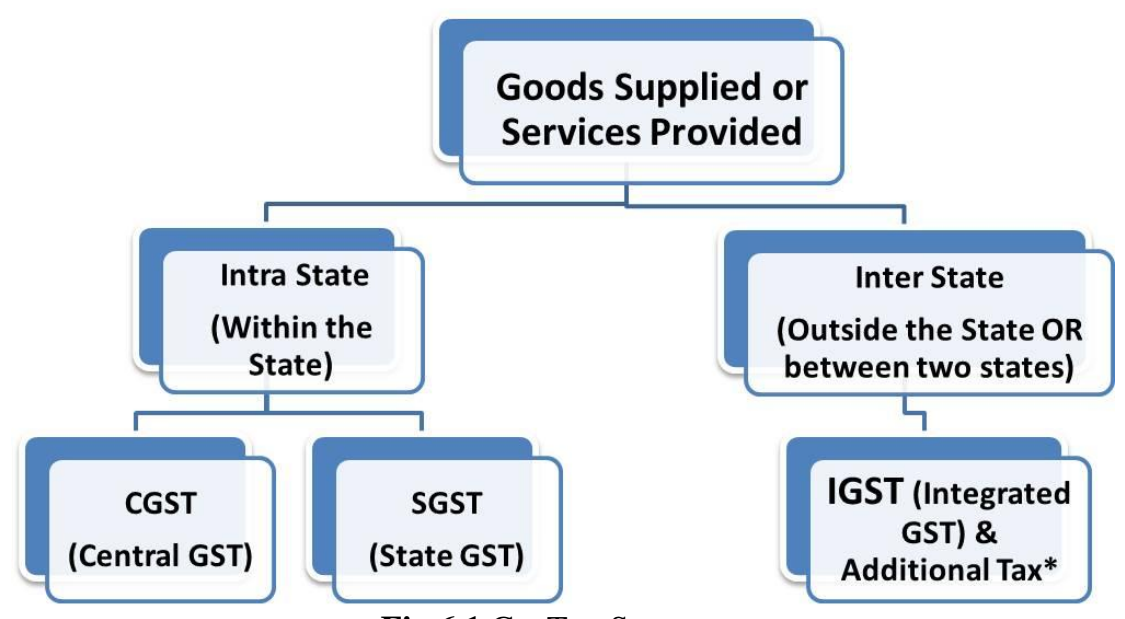

Fig 6.1 Gst Tax Structure

\section{Sale In One State, Resale In The Same State:}

\section{How GST Operates In India?}

The illustration below indicates that goods are moving from Mumbai to Pune. The situation indicates a sale within a state, CGST and SGST will be levied. The levied fares go to the Central Government and the State Government as indicated in the diagram. The goods are resold from Pune to Nagpur. This is a sale again within a state, so CGST and SGST will be levied. Sale price will be increased so tax liability will also duly increase. In the case of resale, the credit of input CGST and input SGST (Rs. 8) is levied as shown; and the remaining taxes go to the respective governments.

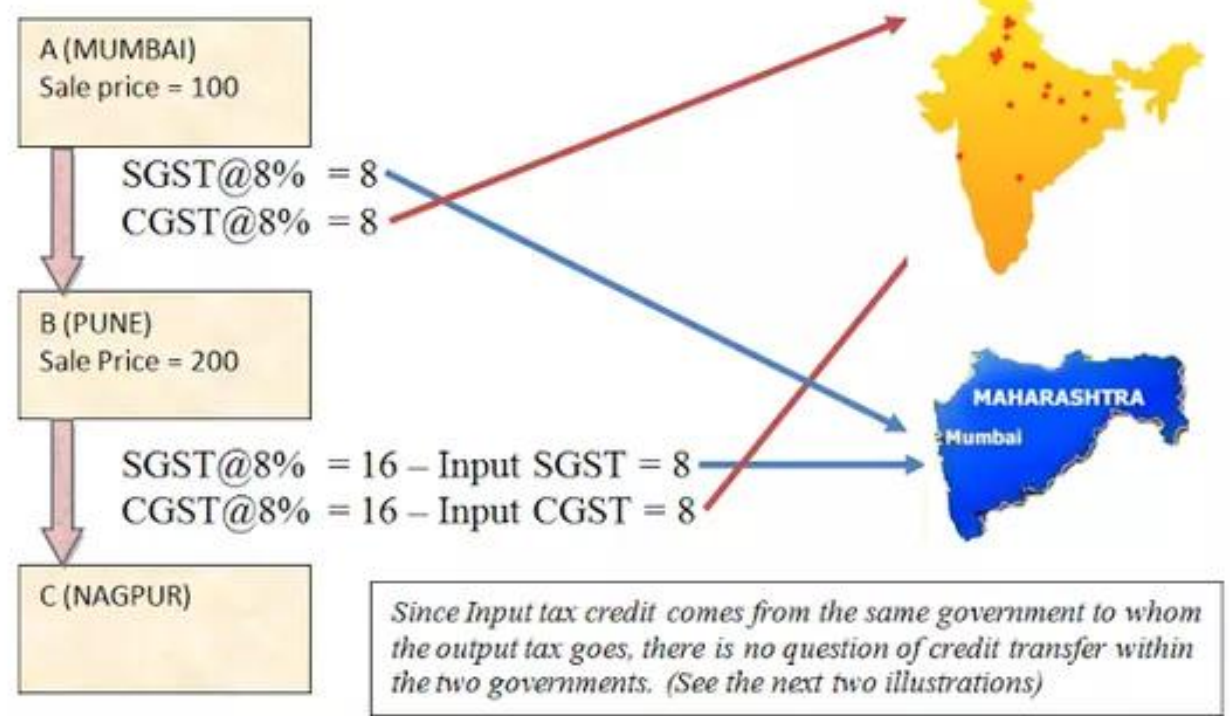

Fig 7.1 Sale In Ine State, Resale In The Same State.

\section{Sale In One State, Resale In Another State:}

The figure 7.2 depicts that the goods are moving from Indore to Bhopal. This indicates a sale within a state, CGST and SGST will be levied. The collection goes to the Central Government and the State Government as indicated in the figure. The goods are the resold from Bhopal to Lucknow (outside the state). Hence, IGST will be levied. The IGST goes to the central government.

The input taxes are taken as credit against IGST.SGST never goes to the central government, still the credit is claimed. This is the crux of GST. Since this amounts to a loss to the Central Government, the state government compensates the central government by transferring the credit to the central government. 


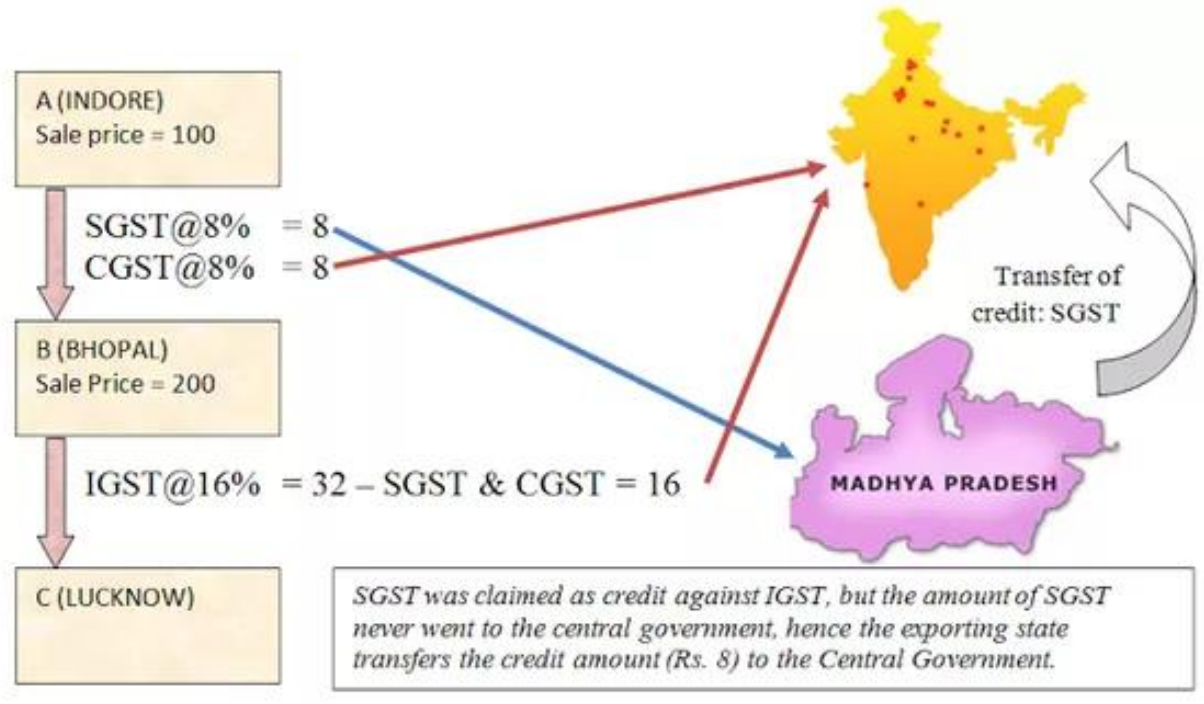

Fig 7.2: Sale In One State, Resale In Another State.

\section{Sale Outside The State, Resale In That State:}

The figure 7.3 indicates that the goods are moving from Delhi to Jaipur. This is an interstate sale hence IGST will be levied. The collection goes to the Central Government. The goods when they are resold from Jaipur to Jodhpur (within the state). The, CGST and SGST will be levied.

Against CGST and SGST, 50\% of the IGST, that is Rs. 8 is taken as a credit. But we see that IGST never went to the state government, still the credit is claimed against SGST. Since this amounts to a loss to the State Government, the Central government compensates the State government by transferring the credit to the State government.

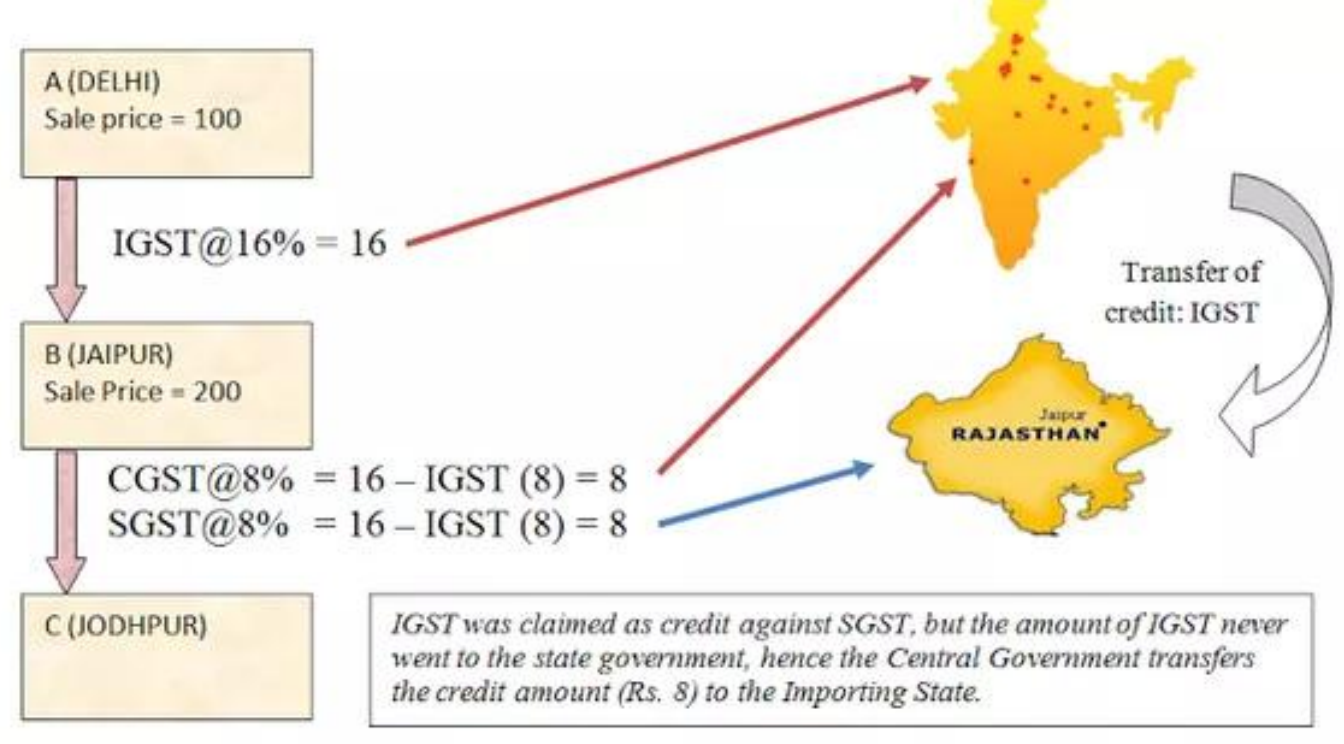

Fig 7.3 Sale Outside State Resale In The State

\section{Salient Features Of GST In India:}

1. The GST would be applicable on the supply of goods and services as against the present concept of tax on the manufacture and sale of goods or services. It would be destination based consumption tax.

2. Dual GST with the center and states simultaneously levying it on a common tax base. Thus would be CGST (central GST) and state GST (SGST).

3. GST would apply to all goods other than alcoholic liquor, liquor for human consumption, and five petroleum products which is crude, motor spirit (petrol), high speed diesel, natural gas and aviation turbine fuel. 
4. Tobacco and tobacco products would be subject to GST.in addition center would have the power to levy central Excise duty on these products.

5. There would be GST council which shall make recommendations to the union and states on taxes, cesses and surcharges levied by the center, the states and the local bodies

6. Taxpayer with the aggregate turnover in a financial year up to Rs 20 lakhs would be exempt from tax. For north east states and Sikkim the exemption threshold shall be Rs 10 lakhs.

7. An integrated GST (IGST) would be levied and collected by the center on inter-state supply of goods and services.

8. Tax payer shall be allowed to take credit of taxes paid on inputs (input tax credit) and utilize the same for the payment of output tax.

9. Import of goods and services would be treated as inter-state supplies and would be subject to IGST in addition to the applicable customs duties.

10. The laws. Regulations and procedures for levy and collection of CGST and SGST would be harmonized to every possible extent.

\section{Impact Of Transitional Phase:}

GST has been introduced in India to ward off the ill effects of wide variety of direct taxes which have proved to be detrimental to the growth and development. This is more evident in the dismal performance of the manufacturing sector which is the life line of our nation.

The various taxes which have been subsumed under GST are given below:

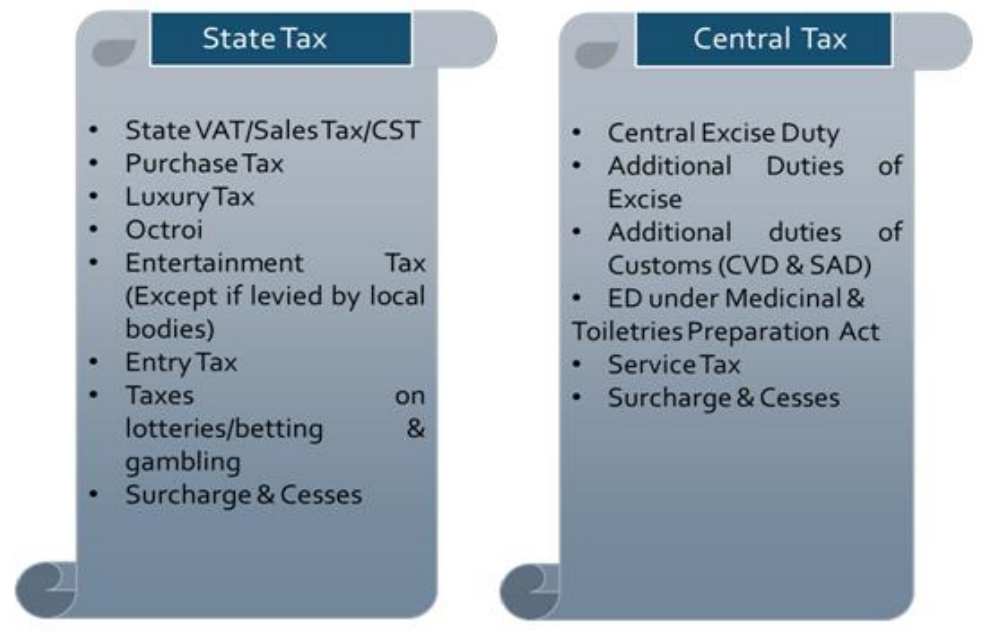

Fig 9.1 State Tax Vs Central Tax

The direct implication of the amalgamation of the above taxes would be diminished cascading effect of multitude taxes .Multitude of taxes reflected in the form of higher prices eventually pinching the final consumers. The reduction of taxes from the consumer's side would stimulate demand both in the domestic market and international market.

Goods and services tax is seen as an historic step towards standardization of the tax rates. Standard taxes would accelerate the production since cost of production would also come down.

Input tax credit which is the soul of GST is seen as a major milestone towards tax liabilities. ITC in simple terms refers to the avail of taxes paid on input stage as credit that can be utilized as set-off for the payment of output tax liability by the tax payer tax is paid only on the value addition rather than on the whole value of his outward supply.

Another unique feature of input tax credit is that it can be claimed only by business registered under GST. The mechanism is simple - the amount of GST incurred on input would be deducted from GST charged on output by registered person.
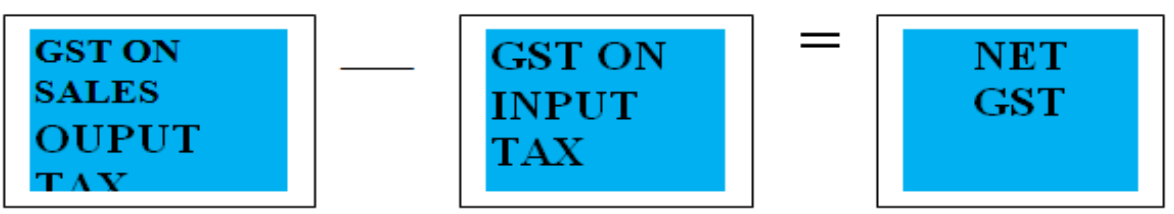


\section{Economic Implications Of GST In India:}

- It would help in lesser corruption and Increased Tax Revenue.

- It contributes towards a Better and improved economy with single taxation. The system will make it easier to identify the tax defaulters.

- The registration of GST will create a unified market. This will help in the facilitation of seamless movement of goods to different states of India and reduce the transaction cost of businesses.

- Tax evasion will be reduced considerably with lower tax cost which will result in better investments in manufacturing industry.

- One tax instead of so many different taxes will make tax compliance and tax monitoring easier.

- Increased investments in manufacturing sectors and reduced cost will result in increased volume of exports.

- Distribution of burden of tax between goods and service industries.

\section{Expected Roadblocks For GST:}

- Goods and services tax is a transitional tax structure which would encompass wide variety of taxes into one. It is perceived to be a reformative tax structure unifying the market and expected to bring substantial increase in countries overall productivity through free movement of goods and services.

- However transitional phase also faces roadblocks as well as lack of clarity till it reaches final implementation. There are few blind spots which needs to be uncovered so that the benefits trickle down to every sector of the economy. One such is the dual structure. A strong mechanism is needed to monitor the tax levied on the origin state till the destination stage. It is essential that the tax payer should feel burden with zealous taxes and his cash flow is uninterrupted.

- In the present tax structure central excise is a tax on manufacturing and therefore is not reflected on invoices issues to final consumers. IN the GST regime, the entire tax liability would be reflected on the invoices which might create an impression of extra taxes or more taxes to be paid by the final consumers.

- The most evident issue is the exemptions of key sectors such as electricity, diesel, petrol,crude oil and real estate. These exemptions may not be able to reduce the cascading effect of indirect taxes as expected.

- The lower house of Indian parliament recently passed four GST legislations. The Bill proposes central GST at $20 \%$ and the Integrated GST rate at $40 \%$.It is believed that the states would cap the State GST rate $20 \%$. These rates could turn out to be counterproductive.

- There are panels expected to overcome these few hitches, however only time and effective implementation would help the nation to reap the benefits of unifying tax structure.

\section{Demonetization: What Does This Mean For GST?}

- The absence of a widespread black market economy encourages more dealers to register under indirect tax acts. The buyers of goods can avail themselves Input Tax Credits (ITC) only on purchases made from registered dealers.

- The incentive structure will motivate buyers to restrain from buying from an unregistered dealer if the option to buy from a registered dealer exists.

- Dealers below the registration threshold will find it an economic necessity to register, in order to survive in the market. Black money eradication will also force dealers to come into the light since no buyers will exist for them.

- Registration of dealers will help to automate the process, which is a prerequisite for GST and will help achieve the aim of unifying the Indian market by identifying each commercial transaction.

\section{Conclusion:}

India's historic and bold move towards integrated tax structure is viewed by most economist as an answer to regressive indirect tax structure. It is believed that GST would put India s indirect tax structure at par with more than 140 countries and would be productive for all the sectors. Implementation of such reforms does faces surmountable challenges, however this is expected to bring in benefits in the form of higher GDP and also transparency in the tax system. The GST would be imposed on the value -addition and thus would leave lesser scope for tax evasion.

\section{Journal Papers:}

[1] Aurobindo Panda, Atul Patel, The Impact of GST on the Indian Tax Scene, SSRN Electronic Journal, July 201, DOI: $10.2139 /$ ssrn. 1868621

[2] Nishita Gupta, Goods and Services Tax: it's impact on Indian Economy, International Research Journal of Commerce Arts and Science, Vol 5, Issue 3, Year-2014, ISSN 2319-9202. 
[3] NehaKanojia, A Study on Goods and services Tax in India, the International Journal of Social science and Management, ISSN: 22511571 .

[4] Monika Sehrawat, UpasanaDhanda, GST in India: A Key Tax Reform, International Journal of Research Granthalaya, Vol 3, No: 12(2015) 133-141

[5] Ethisham Ahmad and SatyaPoddar, GST reforms and Intergovernmental Considerations in India, LSE Asia Research Centre

\section{Magazines:}

[1] ICE magazine, november 2016,'Goods and Services tax -an overview by P.K Mohanty ,consultant ,CBEC

\section{Web Sites:}

[1]. http://www.financialexpress.com/opinion/gst-rate-the-global-picture/348207/

[2]. http://www.financialexpress.com/opinion/gst-rate-the-global-picture/348207/

[3]. http://www.ey.com/in/en/services/ey-goods-and-services-tax-gst

[4]. https://www.quora.com/What-is-GST-in-India

[5]. http://www.gstindia.com/ 